IFN Working Paper No. 707, 2007

\title{
Entrepreneurship and Institutions
}

Magnus Henrekson 


\title{
Entrepreneurship and Institutions*
}

\author{
Magnus Henrekson
}

June 25, 2007

\begin{abstract}
In this paper entrepreneurs are defined as agents who bring about economic change by combining their own effort with other factors of production in search of economic rents. The institutional setup is argued to determine both the supply and direction of entrepreneurial activity. Four key institutions are explored more closely: property rights protection, savings policies, taxation and the regulation of labor markets. Institutions have far-reaching effects on entrepreneurship, and they largely determine whether or not entrepreneurial activity will be socially productive. Due to the responsiveness of entrepreneurship to the institutional setup it is maintained that in-depth analyses of specific institutions are required in order to further our understanding of the determinants of entrepreneurial behavior and the economic effects of entrepreneurship. The paper also demonstrates that it is problematic to use self-employment as an empirical proxy for productive entrepreneurship.
\end{abstract}

JEL Codes: H32; L5; L25; M13; O31; P14.

Keywords: Entrepreneurship; Industrial policy; Innovation; Institutions; Labor security; Property rights; Regulation; Self-employment; Tax policy.

\author{
Research Institute of Industrial Economics (IFN) \\ Box 55665 \\ SE-102 15 Stockholm \\ Phone: +46-8-665 4502 \\ Fax: +46-8-665 4599 \\ e-mail: magnus.henrekson@ifn.se
}

\footnotetext{
* An earlier version of this paper was presented at the conference Entrepreneurship: Law, Culture, and the Labor Market, Chicago, March 23-24, 2007. The conference was hosted by professor Matthew Finkin, College of Law, University of Illinois. I am grateful for useful comments and suggestions from Robin Douhan, Tino Sanandaji and André van Stel. The paper was written within the Gustaf Douglas Research Program on Entrepreneurship at the Research Institute of Industrial Economics, Stockholm.

The author is President of the Research Institute of Industrial Economics and Jacob Wallenberg Professor of Economics at the Stockholm School of Economics in Stockholm, Sweden. He is also chairman of the prize committee for The International Award for Entrepreneurship and Small Business Research (The FSF-NUTEK Award).
} 


\section{Introduction}

In the 1990s entrepreneurship moved to the fore of the economic policy agenda. Many governments, in particular in Europe, came to see the entrepreneur as the solution to weak economic performance and to deficient job creation.

The research community responded to the demand from policymakers with a virtual explosion of entrepreneurship research. Both the number of contributions and the diversity of approaches across the various social sciences have been extraordinary, as even a cursory look through the recent handbooks will demonstrate (e.g., Acs and Audretsch 2003; Shane 2002; and the numerous volumes appearing in Edward Elgar's International Library of Entrepreneurship Series). Entrepreneurship is studied in virtually all disciplines, ranging from social anthropology to organizational theory to mathematical economics. The areas of focus are equally diverse, including personality, opportunity, motivation, environment, organization, coordination, policy, finance and more.

The fact that both policymakers and social scientists have become so interested in entrepreneurship in recent years should of course be applauded. The problem is that “entrepreneurship” and "entrepreneurs” have become overused buzzwords, in particular in the policy debate, but sometimes even in academia. The overuse of the term and the unrealistic expectations have lead to the real risk of a backlash, especially if the entrepreneurs fail to deliver all the great things that were promised by politicians and prophesied by scholars.

The development of entrepreneurship research within economics differs somewhat from other social sciences. For a long time there were rarely, if ever, any entrepreneurs in the models used by neoclassical economists. ${ }^{1}$ There are, however, signs that this is changing. Leading mainstream economists are beginning to make strong claims, such as "the

\footnotetext{
${ }^{1}$ See, e.g., Johansson (2004) who shows that the terms “entrepreneurship” or "entrepreneur" are virtually nonexistent in the leading textbooks in microeconomics and industrial organization used at the graduate level.
} 
entrepreneur is the single most important player in a modern economy” (Lazear 2005, p. 649).

The reason for the disregard of entrepreneurship is not a denial of its significance amongst economic researchers. Since the days of Adam Smith, Joseph Schumpeter and Friedrich Hayek, most economists have acknowledged the crucial importance of entrepreneurs for growth and for the organization of economic activity. The problem is instead methodological, and particular to the formal tools of economics. The entrepreneur and the entrepreneurial function elude analytical tractability. In recent years, several attempts have been made to include these concepts in mainstream economic modeling. Bur it seems from these attempts that entrepreneurship is invariably narrowly defined. While models can analyze some particular aspect of the problem (e.g. risk aversion), no single model has been able to capture the complexity and wide-ranging functions of entrepreneurship developed outside formal economics (Bianchi and Henrekson 2005).

The purpose of this paper is to discuss a number of methodological issues that are often either ignored or treated too light-heartedly in the entrepreneurship and small business economics literature. ${ }^{2}$

A premise underlying many studies (usually implicitly) is that more entrepreneurship is always better. This is not necessarily true, according to most definitions of entrepreneurship. In the next section various definitions of entrepreneurship will be discussed. In section 3 the analysis will be taken one step further, introducing the crucial role of the institutional setup in determining entrepreneurial behavior. The message from this section is that entrepreneurship can only be meaningfully analyzed within a welldefined institutional context. In section 4 I critically discuss whether and to what extent self-employment is a reasonable proxy for productive entrepreneurship. In section 5 it is suggested that entrepreneurship can be seen as a continual quest for economic rents, i.e.

\footnotetext{
${ }^{2}$ I was originally invited to comment on the following four papers: Cowling (2007), Fonseca et al. (2007), Kanniainen and Poutvaara (2007) and Parker (2007). On some occasions I will refer directly to these papers when it can serve to illustrate a specific point. For the most part, however, the paper more generally evaluates some key aspects of the entrepreneurship literature.
} 
rates of return exceeding the risk-adjusted market return. Section 6 explores several key institutions governing the behavior of entrepreneurs. Section 7 concludes.

\section{Defining Entrepreneurship}

Whenever any concept is analyzed in the social sciences the discussion benefits from a clear definition, and from agreement among scholars about the fashion in which it is used. This is unfortunately not the case in the area of entrepreneurship research. Hébert and Link (2006) provide a summary of the vast literature, identifying at least 12 separate definitions (“identities”) that have been used by various scholars. Without delving too deeply into details it is obvious that several of these definitions do not constitute true entrepreneurship (manager, contractor) whereas other categories (owner of a firm, supplier of capital, industrial leader) may be, but are not necessarily entrepreneurial.

So how do I define entrepreneurship? First, it is about individuals and organizations - be they new, old, large or small - that actively contribute to renewal and change in the economy. This can be either Schumpeterian (Schumpeter 1934) entrepreneurship which disturbs an existing equilibrium, or it can be Kirznerian (Kirzner 1973) entrepreneurship, which moves the economy towards equilibrium. It does not really matter whether the entrepreneur is the person who provokes change or merely adjusts to it. Entrepreneurial action can mean both creation of opportunity and response to existing circumstances, where entrepreneurs have the daring to embrace risks in the face of uncertainty.

Second, entrepreneurship is a function, one that is carried out by specific individuals who can by their own volition decide whether to supply this function. Given that they choose to do so, the activities may be productive, unproductive or even destructive from a societal perspective (Baumol 1990; Murphy et al. 1991).

Third, individuals carrying out the entrepreneurial function are self-serving agents, so that we can reasonably assume that entrepreneurs venture into the type of entrepreneurship that they expect will lead to the highest private return. 
Lastly following Wennekers and Thurik (1999), a person can be said to engage in an entrepreneurial venture if she either on her own or in teams, and either inside or outside existing organizations:

- perceives and creates new economic opportunities (new products, new production methods, new organizational schemes and new product market combinations), and

- introduces her or his idea in the market, in the face of uncertainty and other obstacles by making decisions on location, form and the use of resources and institutions. $^{3}$

From this definition of entrepreneurship some noteworthy implications follow. To begin with, entrepreneurship is largely an open-ended process (Kirzner 1997), an important reason why more focus should be given to incalculable uncertainty than to calculable risk. Entrepreneurship almost always entails an ambition to grow. This is normally achieved by hiring other factors of production in the market, while the entrepreneur remains the main or sole residual claimant to the excess value created through the new combination of resources. The legal entity within which these activities are organized is of course normally the firm. However, the distinctions made above underline why selfemployment cannot be equated to entrepreneurship, and why it is likely to be a poor proxy in empirical work. Conversely, employees without an ownership role can also be entrepreneurial (intrapreneurship), although this may be difficult to achieve if it is hard to write compensation contracts that provide the right incentives.

\section{The Crucial Role of the Institutional Setup}

Douglass North (e.g., 1990) criticized the received view that economic growth is caused by the accumulation of factors of production. He claimed that these are just proximate causes of growth. The ultimate causes for development resided instead in the incentive structure that encouraged individual effort and investment in physical and human capital and in new technology. This incentive structure was in turn determined by "the rules of the game in society” or the institutional setup broadly construed. The role of institutions

\footnotetext{
3 This is closely related to Casson's (2003) definition of the entrepreneur as “a specialist in taking judgemental decisions.”
} 
has in recent years re-emerged as a dominant explanation of long-term economic performance. In particular, see Rodrik et al. (2004) and Acemoglu et al. (2005).

Baumol (1990) pioneered the role of institutions for entrepreneurial behavior, viz. how "the social structure of payoffs" channeled entrepreneurship to different activities - some of which are productive, some unproductive and some destructive/predatory. On the surface, the logic is deceptively simple. If institutions are such that it is beneficial for the individual to spend entrepreneurial effort on circumventing them, the individual will do so rather than benefiting from given institutions to reduce uncertainty and enhance contract and product quality. The outcome in this case is expected to be one where corruption and predatory activities prevail over socially productive entrepreneurship.

Baumol simplifies matters somewhat in that he assumes that the supply of entrepreneurial effort in society is constant, so that the institutional setup only matters for its allocation across activities. This is one important aspect of the role of institutions, but the supply of entrepreneurial effort is also likely to be influenced by the institutional setup. Baumol's analysis of non-productive and destructive entrepreneurship is not only applicable to less developed societies. The wealthy world does a good job of directing entrepreneurship towards inherently productive purposes (a large part of the explanation for the wealth), but there are nevertheless many instances of unproductive or predatory entrepreneurship in rich countries as well. Typical examples include the impressive networks of illegal cigarette smuggling and distribution in Sweden or the highly competent and successful lobbying firms in Brussels.

The central conclusion of the discussion above is that entrepreneurs and entrepreneurial behavior can only be evaluated given the institutional context. There is no guarantee that a potential entrepreneur will actually put his or her time and effort to productive use. If the institutional setting encourages behavior that is wasteful or destructive from the point of view of society more entrepreneurship means less prosperity. The existence of externalities does not automatically make entrepreneurship unproductive. New software programs that simplify tax planning may increase tax avoidance, and result in more 
resources being spent by the government on auditing. But they may also reduce the time used by taxpayers on socially wasteful tax avoidance efforts.

In reality, the interaction between various dimensions of the institutional setup and the type and level of entrepreneurial activity is highly complex and therefore difficult to disentangle. A first step towards a better understanding of this complexity is to analyze the different motives for self-employment and whether and to what extent these motives are entrepreneurial.

\section{Self-Employment vs. Entrepreneurship}

In the empirical literature on the determinants of self-employment a distinction is often made between pull and push factors (Storey 1994). An individual can either be pulled into self-employment in order to pursue a lucrative business opportunity (rather than having a regular job, or perhaps not working at all) or s/he can be pushed into it because there is no better choice for making a living. Reynolds et al. (2002) explicitly distinguish between "opportunity-based” and "necessity” entrepreneurship in their annual effort (Global Entrepreneurship Monitor, GEM) to measure the rate of entrepreneurial activity across countries.

It may be useful to distinguish between first-best and second-best solutions, as well as whether the self-employed are entrepreneurial or non-entrepreneurial. Another important distinction is whether the self-employed pursue productive or unproductive/predatory activities (Murphy et al. 1991).

In Table 1 these distinctions are used to identify different motives to start a business. The top row gives society's first-best alternatives. Here, an entrepreneurial business is started because it provides the best vehicle for pursuing a business opportunity. Other, strictly speaking non-entrepreneurial, motives are to give the owner the opportunity to pursue a certain life style, to earn her/his living independently or to facilitate the organization of certain projects best pursued as an independent firm but without being an entrepreneurial 
venture. A franchise could be owned by the manager in order to overcome or mitigate agency problems, without implying any entrepreneurship.

Table 1 Reasons for Self-employment.

\begin{tabular}{|c|c|c|}
\hline & Entrepreneurial & Non-entrepreneurial \\
\hline First best & $\begin{array}{l}\text { Pursue a business opportunity } \\
\text { most suitably pursued in a new } \\
\text { firm }\end{array}$ & $\begin{array}{l}\text { 1. Seeking independence, a } \\
\text { certain life style etc. } \\
\text { 2. Local service production; } \\
\text { working in networks in } \\
\text { temporary projects }\end{array}$ \\
\hline \multirow[t]{4}{*}{ Second best } & $\begin{array}{l}\text { 1. Inferior management by } \\
\text { current employer bars efficient } \\
\text { intrapreneurship }\end{array}$ & $\begin{array}{l}\text { 1. Safety valve to circumvent } \\
\text { excessive labor market } \\
\text { regulations }\end{array}$ \\
\hline & \multirow{3}{*}{$\begin{array}{l}\text { 2. Mechanism to escape effect of } \\
\text { discrimination or lack of social } \\
\text { capital for marginal groups } \\
\text { 3. Necessity entrepreneurship }\end{array}$} & $\begin{array}{l}\text { 2. Means to achieve flexibility } \\
\text { hindered by other regulations }\end{array}$ \\
\hline & & $\begin{array}{l}\text { 3. Mechanism to escape effect of } \\
\text { discrimination or lack of social } \\
\text { capital for marginal groups }\end{array}$ \\
\hline & & 4. Necessity entrepreneurship \\
\hline \multirow[t]{2}{*}{$\begin{array}{l}\text { Unproductive/ } \\
\text { predatory }\end{array}$} & \multirow{2}{*}{$\begin{array}{l}\text { 1. Set up a business to exploit } \\
\text { subsidies and tax breaks rather } \\
\text { than create value for customers } \\
\text { 2. Fraudulence } \\
\text { 3. Looting, warfare etc. }\end{array}$} & $\begin{array}{l}\text { 1. Transform consumption } \\
\text { expenditure into tax deductible } \\
\text { business costs }\end{array}$ \\
\hline & & $\begin{array}{l}\text { 2. Fraudulence, where revenue is } \\
\text { partly unreported etc. }\end{array}$ \\
\hline
\end{tabular}

Note: The table lists the major motives for self-employment. There are also intermediate cases. Entrepreneurial self-employment may, for instance, be partly pursued in search of independence.

In the second-best case the entrepreneurial motives arise as a result of various obstacles barring the optimal outcome. Entrepreneurship here provides a means to circumvent obstacles that could emanate either from inappropriate institutions or from within the private sector. For instance, inferior management and business organizations may prevent an intrapreneur from introducing and reaping the rewards from his or her ideas.

Legislation could ban the use of stock option incentives to encourage intrapreneurship or it could make it prohibitively expensive. A last example is how various forms of discrimination often hinder marginal groups from seeking regular employment, leaving 
self-employment as the remaining opportunity. Other incentives are also at work, becoming self-employed can for instance be a way to escape restrictive employment regulation or pay schedules. This kind of entrepreneurship may be called evasive (Coyne and Leeson 2004). Evasive entrepreneurship may also consist of efforts to evade the legal system or to avoid the predatory activities of other agents. Tax evasion and bribes paid to regulators or inspectors used to evade onerous regulations are two examples. Hence, formally illegal evasive activities may in some systems be necessary in order to achieve productive entrepreneurship. ${ }^{4}$

In the most unfavorable outcome, the incentives are such that entrepreneurs strive to exploit the business opportunities arising from the regulation itself. Entrepreneurial incentives to start a business may then be geared towards exploiting tax breaks and subsidies rather than creating value. Sidestepping or reducing the impact of taxes and other legislation are also the prime motives for non-entrepreneurial businesses under this kind of regime. In cases where the government does not manage to uphold a monopoly on violence and where the rule of rule law does not prevail, entrepreneurship may also take on highly destructive forms such as looting and private warfare.

In a world where institutions were such that there were no opportunities for unproductive or predatory entrepreneurship and a world of perfect contracts where productive entrepreneurship could always be pursued efficiently within existing firms, the only reason to be self-employed would be the personal quest for independence. Even independence could perhaps theoretically be arranged through advanced contractual arrangements inside the organization. This state of affairs is of course far from reality. In fact, the long period during which large firms had predominated while small firms had been increasingly marginalized came to an end in the 1970s. Entrepreneurship and small firms experienced a global resurgence (Loveman and Sengenberger 1991). Scholars have suggested several first-best reasons why this occurred (Acs 1999). Furthermore, in reality there exists no economic system where the institutional setup is entirely "appropriate"

\footnotetext{
${ }^{4}$ See also van Stel et al. (2007), who argue that institutions determine the distribution of business activity between the formal and informal sector of the economy.
} 
(Gerschenkron 1962) in the sense that there are no second-best reasons for selfemployment and no opportunities for unproductive or predatory self-employment.

In sum, from a societal perspective the aggregate level of self-employment, measured as the rate of self-employment, is not necessarily a meaningful measure. In order to evaluate whether there is too much or too little self-employment one needs to decompose the aggregate carefully and make it contingent on the institutional setup. Based on this fact, some skepticism is warranted towards results from cross-country studies using the rate of self-employment as a measure of entrepreneurial activity. ${ }^{5}$

\section{Entrepreneurship as the Creation or Discovery of Rents}

In section 2 it was pointed out that entrepreneurship entails the discovery or creation of new economic opportunities. Several distinct types of entrepreneurship were also identified: productive, unproductive, evasive and predatory/destructive. The types of entrepreneurship are defined based on the social value of the expended entrepreneurial effort. However, when seen from the perspective of the self-serving entrepreneur entry is based on which type of entrepreneurship that is expected to have the largest private return. ${ }^{6}$ A venture that is highly profitable for the individual entrepreneur may give rise to large social losses.

One fruitful way to analyze entrepreneurship is to posit that entrepreneurs are searching for rates of return exceeding the risk-adjusted market rate of return, i.e. they try to create or discover economic rents. In other words, entrepreneurship may be seen as rent seeking. ${ }^{7}$ The entrepreneurial rent arises when entrepreneurship is combined with the use

\footnotetext{
${ }^{5}$ Two recent examples are Blanchflower (2000) and Carree et al. (2002). van Stel et al. (2005) instead use the GEM measure of total entrepreneurial activity to explain cross-country growth differentials. However, the same criticism largely applies to this measure as well.

${ }^{6}$ This maximizing behavior does necessarily imply narrow selfishness. The entrepreneur could care about the welfare of kin and friends, or even about the welfare of the general public. It suffices that the business decisions are decoupled from such considerations. The entrepreneur maximizes profits selfishly, but no constraint is put on the use of the profits. They may or may not be spent with altruistic considerations.

${ }^{7}$ It should be noted that the term is not used in the constrained way usually applied in Public Choice to "describe behavior in institutional settings where individual efforts to maximize value generate social waste
} 
of other inputs such as capital and labor. Yet, neither in the conventional financial accounts at the firm level nor in the national accounts is there an item entitled entrepreneurial income. In the case where the entrepreneur is also the business owner successful entrepreneurship will instead show up as high rates of return on equity and/or as high labor income earned by entrepreneur. Given asymmetric information and moral hazard, the risk-adjusted rate of return demanded by external investors may of course be extremely high in some cases, often so high that the entrepreneur cannot become a qualified entrepreneur unless s/he can finance the venture out of her/his own wealth. Likewise entrepreneurs may face a high cost of labor, including being forced to concede stock options, if potential workers perceive that the venture is highly uncertain and demands firm-specific human capital investments from them. If an entrepreneurial venture turns out to be successful, the risk premium demanded by outside financiers (at some point debt financing also becomes available) and potential workers will decline and the rate of return required for obtaining a positive entrepreneurial rent also declines.

It is useful to distinguish between two types of entrepreneurial rents, namely Ricardian and Marshallian rents. ${ }^{8}$ David Ricardo defined rents as return to a factor of production exceeding the level necessary to ascertain its supply. Scarce land and unique pieces of art are typical examples. Entrepreneurs may create Ricardian rents in several ways, perhaps most obviously through the patenting of valuable innovations and copyright. They can also protect all or some of their innovations themselves through rent protecting techniques, in general acquiring some resource that potential competitors cannot easily obtain. One example is the implementation of tacit knowledge in organizations that is hard to imitate. Still, most rents do not last forever, in particular if they rest on a fixed supply of a factor that is man-made. First, patents and copyrights are only granted for a fixed time period. Second, in the long term competing firms will normally come up with substitutes to the product yielding a Ricardian rent, sometimes by producing a completely different product that fills the same basic need or by developing a new mode of production. These effects tend to erode the rent in the longer term, since the scarce

rather than social surplus” (Buchanan, 1980, p. 4). In that tradition, rent-seeking is an activity which, by definition, generates social loss. That can be seen as a specific subset in our general framework.

${ }^{8}$ See also Lewin and Phelan (2002) and Alvarez (2005) for a discussion of entrepreneurial rents. 
resource is only fixed or highly constrained for some time. Such temporary rents are usually called Marshallian or quasi rents. See Table 2.

Table 2 Types of Entrepreneurial Rents.

\begin{tabular}{ll}
\hline Ricardian rent & $\begin{array}{l}\text { an entrepreneurial discovery or creation that requires a } \\
\text { resource where the supply is fixed (unique competence, } \\
\text { organizational advantage that cannot be imitated, patent, } \\
\text { copyright, locational advantage etc.) }\end{array}$ \\
$\begin{array}{l}\text { Marshallian rent } \\
\text { (quasi rent) }\end{array}$ & $\begin{array}{l}\text { an entrepreneurial discovery or creation that requires a } \\
\text { resource where the supply is fixed or highly constrained } \\
\text { for some significant period of time (organizational } \\
\text { superiority, patent protection of limited duration, creation } \\
\text { of a strong brand name etc.) }\end{array}$ \\
\hline
\end{tabular}

The difference is one of degree, depending on how fast the rents are eroded. The duration of rents varies substantially. Rents that exhibit the fastest decay pertain to activities which are easy to imitate and where the knowledge or skill is not embodied in a specific individual or organization. In such cases, the knowledge is easily transmitted at low cost and is expected to rapidly disseminate through the economy. Normally, imitating competitors enter the market, which increases the supply and lowers the price. According to calculations by Nordhaus (2004), entrepreneurs retain on average a mere two percent of the total societal surplus generated by their activities.

However, each firm is at the same time a unique combination of resources and technologies. A particular combination of human capital and entrepreneurial talent can in some cases result in a company where productive entrepreneurship is greatly facilitated. Such firms cannot at any reasonable cost be replicated, and the rents generated thus seem to be Ricardian.

The Ricardian and Marshallian rents are generated when resources and technology are put to use in a way that cannot (at least in the short run) be replicated by other agents. But what if replication cannot occur because of government entry regulations? In other 
words, what about a monopoly situation? Such rents seem, prima facie, to be different from the ones discussed as Ricardian and Marshallian rents; they are dependent on some formal privileges, awarded only to a subset of all entrepreneurs. This is, however, an artifact of not taking institutions into account when discussing entrepreneurship. The easiest way to see this is to consider the case of patent protection of an innovation. Obviously, the expected rent from an innovation depends on the duration of the patent protection. The flip side of patent protection is a barrier to entry for other entrepreneurs. The cost for the latter is especially high if certain firms are better at innovation and others at cost reduction and marketing. Intellectual property rights tend to involve a tradeoff between the two costs.

Hence, we characterize entrepreneurs as rent seekers, i.e., individual agents with particular talents for the pursuit of economic rents. Rents can be obtained in many ways, such as by introducing an innovation, attaining a monopoly position through a government license, earning arbitrage profits and bribing an official to keep competitors out.

Entrepreneurial rents should not be considered as excess return that can be taxed away with no behavioral effects. Instead, it is the ubiquitous quest among entrepreneurs to create and/or discover entrepreneurial rents that gives rise to the continuous structural change and dynamism that is necessary for economic development (Caballero 2007). If the supply of entrepreneurial effort is elastic with respect to the rents it could be argued that the entrepreneurial rents are conceptually not much different from the rent of workers (wage income) and the rent earned by savers (interest rate).

Treating the entrepreneur as a rent seeker introduces a change in perspective, where the entrepreneur is analyzed at the individual level. As such, entrepreneurs are responsive to incentives embedded in their environment. 


\section{Exploring the Effects of Institutions on Entrepreneurship}

I will now briefly explore the effects of four pertinent institutions in order to illustrate at some length why entrepreneurship can only be meaningfully analyzed and understood given the institutional context. ${ }^{9}$

\subsection{Protection of Property Rights}

Based on broad historical studies such as Rosenberg and Birdzell (1986) and North (1981) and more recent econometric studies such as Rodrik et al. (2004) and Acemoglu and Johnson (2005), it is now widely recognized that protection of private property rights is of fundamental importance for economic growth. With secure exclusive private property rights which can be used in voluntary exchanges based on contracts, productive entrepreneurship is likely to thrive. This follows because successful entrepreneurs know that they will retain the entrepreneurial rents they earn and because specialization and the division of labor is greatly facilitated, which broadens the range of potential entrepreneurial discoveries.

But weaker property rights will spur other types of entrepreneurship including the production of (increasingly diverse and sophisticated) private security services. The weaker the property rights, the more predatory the entrepreneurial activities are likely to be. This is obvious from a simple comparison of contemporary Zimbabwe and Russia with countries like the U.S. or Finland. On the other hand, today’s China shows that selfemployment and entrepreneurship (some of which is evasive and unproductive) provides an important avenue for overcoming the impediments caused by weak property rights protection. Thus, all forms of entrepreneurship are likely to co-exist when private property rights are insecure; although it is clear that below some threshold level property rights protection is so low that anarchy ensues (Sierra Leone and Zimbabwe are two recent examples).

\footnotetext{
${ }^{9}$ There are a number of additional institutions that are likely to be important determinants of the incentives for entrepreneurship, e.g., the regulation of product markets, start-up costs, the regulatory burden on firms, the social security system and cultural values vis-à-vis entrepreneurship and self-employment. See, e.g., Parker (2007), van Stel et al. (2007), Kanniainen and Poutvaara (2007), and Hessels et al. (2006).
} 
This point is well illustrated in Coyne and Leeson's (2004) study of entrepreneurship in Romania. They conclude that (p. 243): “There are two ways to interpret the situation in Romania. The standard interpretation, reflected in reports by development agencies, is that there are high barriers to entrepreneurs and, hence, a shortage of entrepreneurship. Another interpretation is that entrepreneurship in Romania is flourishing. The key is the distinction we made between productive, unproductive and evasive entrepreneurship. Productive entrepreneurship is currently stagnant in Romania. Unproductive and evasive entrepreneurship, on the other hand, are alive and well.”

Still, there may also be counteracting effects; if intellectual property rights protection is overly strong, innovativeness may be stifled by large incumbent firms that spend large resources on defensive patenting and purchases of patents from small innovators in order to reduce competition, or if firms file patents for ideas, business models, software strings etc. that are obvious and have been around for quite some time without somebody having tried to patent them before (Cohen 2005). As documented by Jaffee and Lerner (2004) changes in the procedure for the granting of patents in the early 1990s has resulted in a deluge of patents and patent suits. Shapiro (2001) describes the US.S. intellectual property landscape as a "patent thicket”. Even an inventor with a truly novel idea has to face a great risk of running up against related patents whose holders may sue for infringement. This overburdened system of excessive protection of property rights functions as a tax on innovation, in that both the risk and expected expense associated with innovative activity rises sharply. For obvious reasons it also benefits large incumbent firms with financial strength and a great deal of legal expertise relative to small start-ups.

We conclude this subsection by noting that secure property rights in the basic sense is likely to spur productive entrepreneurship. On the other hand, it is in fact likely to reduce entrepreneurship as usually measured, since the need for evasive entrepreneurship to offset weak property rights is likely to go up. The same is true for unproductive and predatory entrepreneurship, since the opportunities for entrepreneurship aiming at the 
redistribution of income and wealth proliferate when property rights are weakly protected or largely undefined. Finally, in recent years the protection of intellectual property has been strengthened in ways that raises both the cost and risk associated with innovative activity. This excessive protection of property rights is likely to impede productive entrepreneurship, but it also spurs evasive and unproductive entrepreneurship to circumvent and to exploit the excessive protection of intellectual property.

\subsection{Savings and Wealth Formation}

There are numerous research results suggesting that strong incentives for saving and individual wealth accumulation are likely to raise the propensity to entrepreneurship. The availability of equity financing is a critical factor for both startups and the expansion of existing firms. In general, the riskier the business, the greater is the reliance on equity relative to debt financing. The smaller and newer the firm, the more difficult for outside financiers to assess the viability and profitability of the venture proposed. Thus, ceteris paribus, small and newly established firms are more dependent on equity financing than large, well-established firms. Low private savings also exacerbate the inherent problem caused by asymmetric information, since wealth-constrained would-be entrepreneurs are unable to signal forcibly to outside investors by means of making sizeable equity infusions of their own, or, if needed, fully finance the firm until the stage where organic growth based on retained earnings is possible.

There is also substantial scientific evidence supporting the idea that the individual wealth position has important effects on the probability of becoming an entrepreneur and on the propensity to expand. This is perhaps the most well-established finding in the small business economics literature; see Parker (2004, chapters 5-7) for an overview.

At the aggregate level it is easy to find supportive prima facie evidence of this.

Entrepreneurial activity as conventionally measured tends to be low in the mature welfare states in northern Europe. Welfare state provisions remove a number of savings motives for the individual. As long as unemployment insurance, income-dependent pensions and sick-leave benefits, higher education and highly subsidized health and care services are 
provided by the government, most of the essential savings motives for the average person disappear.

But the verdict is not that clear cut. The U.S., which is generally considered highly entrepreneurial, has a low savings rate. Young (1992) documents that for a long time savings rates were about double in Singapore compared to Hong Kong, and the latter economy was considered to be the more entrepreneurial of the two, while the GDP growth rates were similar. In contemporary China personal savings are extremely high (in excess of 30 percent of disposable income) without spurring entrepreneurship and business formation commensurately. This partly results from a lack of an insurance system that can substitute for the traditional family during a phase of rapid industrialization and sharply reduced fertility (Lindbeck 2006), but also the lack of secure property rights, the absence of land titles and poorly developed financial markets that can channel funds from savers to entrepreneurs.

In an economy with a well-developed financial sector there is a whole spectrum available ranging from highly liquid savings that are readily available to long-term institutionalized pension saving schemes which put severe restrictions on the owner's control of the assets. In many countries the bulk of personal savings is in the form of long-term pension savings, often tied to employment. In addition, pension savings is often tax favored. Peter Drucker warned against these tendencies more than thirty years ago (Drucker 1976), when he claimed that the trend towards sharply increased saving in the form of corporate pension plans was a dire threat to the entrepreneurial society when it concentrated too much power in too few hands.

Hence, the composition, and not just the volume, of saving is of importance for entrepreneurship. For this reason, any social arrangement that channels savings and asset control to large institutional investors is likely to limit the supply of financial capital to potential entrepreneurs. 


\subsection{Taxation}

In principle, taxation is an infringement on private property rights since it implies that the government has a stake in an individual's income or assets. The effect of taxation on entrepreneurship has been much discussed in economics. Following Domar and Musgrave (1944) high income taxes have been claimed to encourage self-employment both because the self-employed can more easily avoid reporting some of their income or they may be able to shift from labor income taxed at a high marginal rate to corporate income taxed at a lower rate (Feldstein and Slemrod 1980).

However, these mechanisms are too simplistic to assess the effect of taxation on entrepreneurship. To begin with, income from entrepreneurial activities is not a separate income category in the tax code. Hence, from a tax perspective entrepreneurial income can show up in many different forms: labor income, dividends, capital gains, capital gains on stock options, interest income on lending by the entrepreneur to his/her own business and so on.

Given the complexity of the tax code in a typical OECD country it is obvious that the incentive effects of the tax code on entrepreneurial behavior are also highly complex. Some features are likely to be of particular relevance.

King and Fullerton (1984) document that by the 1970s effective tax rates on business income came to differ tremendously by source of finance and ownership category in rich countries. Debt was the most tax-favored form of financing, and new equity issues were the most penalized. In general, business ownership positions held directly by individuals and families were taxed much more heavily than other ownership categories. The wave of tax reforms that swept the OECD in the 1980s evened out many of these differences (Jorgenson and Landau 1993).

These differences in effective tax rates have potentially powerful effects on the organization of business activity and the industry mix of productive activity, and therefore also on the incentives for entrepreneurship. To the extent that debt financing is 
less costly and more readily available for larger and more firmly established firms, high statutory tax rates coupled with tax-deductible interest payments work to the disadvantage of smaller firms and potential entrepreneurs. Debt financing is also more easily available to firms with ready forms of collateral. Hence, firms and sectors that intensively utilize physical capital reap greater benefits from tax code provisions that favor debt financing. This aspect of the tax system favors capital-intensive industries and modes of production relative to labor and knowledge intensive ones, which is likely to work to the detriment of entrepreneurial, often equity-constrained, firms.

Many economic activities that are highly substitutable between market provision and home production (e.g., cooking, cleaning, laundering, landscaping, home repairs) offer greater than average scope for self employment, employment in small firms, startups, and family-owned businesses. Hence, the effective tax rates on labor income and business income accruing directly to households provides yet another channel determining to what extent these activities are open for entrepreneurial exploitation.

To a large extent the return on entrepreneurial effort is taxed as wage income. First, the tax code may restrict the extent to which income accruing from closely held companies may be taxed as capital income. Second, a great deal of the entrepreneurial function is carried out by employees without an ownership stake in the firm, and for them the labor tax schedule is always applicable.

A further mechanism to encourage and reward entrepreneurial behavior among employees is stock options. The efficiency of stock options is highly dependent on the tax code. If the gains on stock options are taxed as wage income when the stock options are tied to employment in the firm this mechanism will lose much of its incentive effects. The situation would be very different if an employee who accepts stock options can defer the tax liability to the time when the stocks were eventually sold. This effect would be further reinforced if there are no tax consequences to the employee upon the grant or the exercise of the option and if the employee is taxed at a low capital gains rate when the stock acquired from the exercise of the option is sold. In the latter case the tax risk of the 
options are pushed back to the government. This accomplishes two things: it increases the potential profit from the stock options and it allows budget-constrained individuals to sell stocks whenever they chose to do so. The U.S. changed the tax code in the early 1980s along the latter lines, which paved the way for a wave of entrepreneurial ventures in Silicon Valley and elsewhere (Misher 1984).

Venture capital firms can also play a crucial role in the development of a small entrepreneurial venture by converting high-risk opportunities to a more acceptable risk level through portfolio diversification, and adding key competencies that the firm may be lacking. This is achieved by means of developing arrangements that align the incentives of the three agents - investors, venture capitalists and entrepreneurial start-ups (Zider 1998; Gompers and Lerner 2001). The extent to which this is possible is also largely governed by the tax code for stock options, capital gains, and whether pension funds are allowed to invest in high risk securities issued by small or new companies and venture capital funds.

A further effect may be that certain actors such as private equity firms can act from offshore tax havens putting them at an advantage relative to individual entrepreneurs. If this effect is present it is increasing with respect to the effective tax rates levied on entrepreneurs legally domiciled onshore.

To sum up, high taxes may spur self-employment but reduce productive entrepreneurship. ${ }^{10}$ On the other hand, a high aggregate tax rate is normally associated with a generous welfare system, which reduces the push into self-employment. Moreover, high tax rates encourage entrepreneurship in the black market and evasive entrepreneurship such as the production of legal services helping productive entrepreneurs to lower their effective tax rate. But most importantly high effective tax rates tend to benefit large incumbent, capital intensive firms that can have high debt equity ratios and be owned by institutions, in particular if they are domiciled in tax havens. All in all there is reason to believe that high taxes stifle productive

\footnotetext{
${ }^{10}$ Empirically, it has been difficult to establish a negative relation between tax levels and the rate of selfemployment. Schuetze and Bruce (2004) conclude that the evidence is inconclusive.
} 
entrepreneurship, although this effect can be greatly mitigated if the taxation of capital gains and stock options is low.

\subsection{Labor Market Regulations}

The degree of regulation of labor markets and wage-setting can be expected to influence incentives for entrepreneurship, since it restricts the freedom of contracting and therefore curtails the possible combinations of factors of production. There are also large crosscountry differences in the extent of labor market regulation. OECD (1994) compares the extent of government regulations on labor standards by measuring five different aspects: working time, fixed-term contracts, employment protection, minimum wages and employee representation rights. In each of these aspects, a country is ranked on a scale of 0,1 , and 2 , where a 2 represents the highest degree of regulation. Adding the five aspects together produces an index ranging in value from 0 to 10 . Of the 18 countries included in the survey, Greece and Sweden exhibited the highest index value (8 and 7 points, respectively). The average for all European countries was 4.9. The U.S. scored a zero and Canada 2.

There are reasons to believe that strict employment security provisions and other regulations that restrict contracting flexibility are more harmful for smaller and/or more entrepreneurial employers. One reason involves the gains from efficiently matching heterogeneous workers to a variety of tasks and positions. As an employer learns about a worker's abilities over time, or as those abilities evolve with the accumulation of experience, the optimal assignment of the worker to various tasks is likely to change. The scope for task reassignment within the firm can also be expected to rise with firm size. In an unfettered labor market, optimal task reassignment often involves mobility between firms, and such mobility is more likely when the initial employment relationship involves a small business. Moreover, both the rate at which workers separate from jobs and the rate at which employers destroy job positions decline with the size, age and capital intensity of the employer (Brown and Medoff 1989; Davis and Haltiwanger 1999). Caballero (2007) also shows that the gross flow of workers is higher in firms with high productivity growth. These patterns in worker separation and job destruction rates suggest that any costs imposed by labor security regulation are likely to fall more heavily on younger, smaller and less capital-intensive employers. To the extent that 
entrepreneurial firms are overrepresented in these categories, labor security regulation disproportionally burden entrepreneurial firms.

Finally, a strictly applied "last in - first out" principle in case of redundancies implies that tenure at the current employer becomes relatively more important for labor security than individual skill and productivity. This fact increases an employee's opportunity cost of changing employers or of leaving a secure salaried job to become self-employed.

Another labor market arrangement that may impact on the incentives for entrepreneurship is wage-setting institutions. Institutional pressures for wage compression are likely to disadvantage smaller and more entrepreneurial businesses. Wages are consistently higher at larger employers, even after exhaustive efforts to control for observable worker characteristics and other job attributes. ${ }^{11}$

If regular employment is highly regulated there may be strong incentives to devise arrangements that circumvent the regulations. In several European countries new forms of flexibility have emerged, which has created more job opportunities than otherwise (Blau and Kahn 1999). The most important of these arrangements are increased selfemployment, the emergence of an underground economy where the government refrains from enforcing regulations and growth of temporary employment. It is likely that part of the increase in self-employment in recent years is driven by such considerations.

To sum up, there is quite a bit of evidence pointing towards differential effects of labor market regulations and non-decentralized wage-setting arrangements. Small and entrepreneurial firms appear to be disadvantaged. However, rigid regulation may in itself spur various entrepreneurial responses to offset and circumvent the rigidities. Selfemployment is one important way, since compensation and working hours are totally unregulated and no labor security is mandated. Also very small firms may be able to avoid unionization and the signing of collective agreements, and therefore benefit from greater freedom of contract. On the other hand, this room of maneuver is likely to be lost once the firm size exceeds a certain threshold. These opposing effects are also consistent

\footnotetext{
${ }^{11} \mathrm{Oi}$ and Idson (1999) review the evidence in this regard.
} 
with the findings of Robson (2003) and Torrini (2005), who do not find any relationship between the rate of self-employment and the degree of regulation of labor markets in rich countries.

The differential effect of labor market regulations may go a long way towards explaining why the rate of self-employment is fairly low in the U.S., while it is very high in Italy. One may hypothesize that in the U.S. the really good entrepreneurial firms become fastgrowing gazelles (Birch and Medoff 1994), while the heavy regulations (and high tax rates on labor) make it difficult and risky to build large firms in Italy. Instead the firms tend to remain small and resort to a strategy of cooperation with other small firms in clusters (Lazerson and Lorenzoni 1999). A comparison of Sweden and Denmark provides another illustration of this general point. The Danish so-called flexicurity model, where hiring and firing can be done at low cost, differs greatly from the Swedish Model, where workers can only be dismissed in case of redundancies ${ }^{12}$ and number of years of tenure at the present employer determines the order of dismissal (Andersen 2007). Although large firms are more predominant in Sweden than in Denmark, the Swedish self-employment rate is nevertheless higher.

\section{Conclusions}

In this paper entrepreneurs have been characterized as rent seekers. ${ }^{13}$ Rent seeking entails an attempt to reap rewards in excess of the level determined in competitive equilibrium. There are numerous means by which rents can be obtained, e.g. introducing a new innovation in the form of a superior product or a more cost-effective mode of production, attaining a monopoly position by virtue of being granted a government license, arbitrage profits, bribing an official to keep competitors out, and, in extreme cases, even looting and private warfare.

\footnotetext{
${ }^{12}$ Excepting gross misconduct, which is very hard to prove for the employer.

${ }^{13}$ For a full-fledged analysis where the rent seeking entrepreneur is integrated into a growth system, see Douhan and Henrekson (2007).
} 
Although productive entrepreneurship is a key factor in any prosperous and dynamic economy, it is still true that entrepreneurship is not inherently socially productive. This is easy to understand if we consider that although the human species has harbored a potential for productive entrepreneurship for tens of thousands of years there are no clear signs of an entrepreneurially driven growth process until a few hundred years ago. The requisite institutions were not in place. Gradually this changed when financially weak rulers were forced to concede more and more property rights to other groups. As shown by Baumol (2002, chapter 5) it gradually became apparent that more economic freedom spurred economic growth, something that gave liberal kingdoms an upper hand. Thus, entrepreneurs' positive and productive response to institutional change created a shift in power, which further reinforced the move towards protection of private property.

This account entails a strong claim that the rules of the game, or the institutions, largely determine how and where entrepreneurial talent and effort is channeled and the extent to which it is supplied. In my view, the larger lesson from these observations is that entrepreneurship cannot be studied without taking institutions into account. Entrepreneurs are always responsive to the incentives embedded in the environment in which they act, and they may even expend entrepreneurial effort to try to change the institutions (Daokui Li et al. 2006).

The effect of institutions on entrepreneurship was explored by looking more closely into four key institutions in this respect, namely the protection of private property rights, savings policies, taxation and the regulation of labor markets. The two most important conclusions from this analysis are that (i) institutions have far-reaching effects, and (ii) to identify these effects on productive entrepreneurship, the respective institutions have to be studied in depth. The Devil is in the details!

The institutional analysis also makes clear that it is problematic to use the rate of selfemployment as a proxy for productive entrepreneurship. There are numerous reasons for becoming self-employed, and in many cases it is a second-best response to unfavorable institutions. This observation alone justifies a sound skepticism of many of the cross- 
country studies trying to explain the variation in entrepreneurial activity using selfemployment as a proxy measure.

Hence, entrepreneurship is an elusive concept; it is both analytically intractable and hard to measure. So where does this leave us? Should we despair and give up on trying to show that entrepreneurship is an essential function in a dynamic economy? Not at all, but we should heed the fact that the data used in our analyses were generated in a particular institutional environment.

Still, an exhaustive characterization of the institutional setup is not feasible, but the crucial elements can and should be identified. Here, entrepreneurship research has a great deal to learn from labor economics, where considerable knowledge has been gained from the study of quasi experiments, often using instrumental variable techniques; see Angrist and Krueger (2001). There are many possible instances that could be utilized. Let me just mention two: (i) the different strategies by universities vis-à-vis the involvement of their faculty in the commercialization of research (Siegel et al. 2003); (ii) the lessening of the employee protection legislation in Sweden in 2001 for firms with fewer than 10 employees (Lindbeck et al. 2006).

In short, the main message of this paper is that analyses of entrepreneurship should be conducted through the lens of the institutional setup. Few, if any, societies have managed to completely quell the individual's innovativeness and pursuit of personal gains. However, there are large differences as to whether and to what extent they have managed to gain rather than lose from these human traits. Although we may be fairly confident that these differences have a great deal to do with institutional differences, we still know little at a more detailed level how these effects are borne out, and how entrepreneurs would react to specific institutional changes, let alone when and how entrepreneurial effort is expended to induce institutional change. There is no lack of important questions for future research in this area. 


\section{References}

Acemoglu, Daron and Simon Johnson (2005), “Unbundling Institutions.” Journal of Political Economy, 113(5), 947-997.

Acemoglu, Daron, Simon Johnson and James A. Robinson (2005), "Institutions as the Fundamental Cause of Long-run Growth.” In Philippe Aghion and Steven Durlauf, eds., Handbook of Economic Growth, Amsterdam: North-Holland.

Acs, Zoltan J., ed. (1999), Are Small Firms Important? Their Role and Impact, Dordrecht: Kluwer.

Acs, Zoltan J. and David B. Audretsch, eds. (2003), Handbook of Entrepreneurship Research, Boston: Kluwer.

Alvarez, Sharon A. (2005), "Theories of Entrepreneurship: Alternative Assumptions and the Study of Entrepreneurial Action.” Foundations and Trends in Entrepreneurship, 1(2), 105148.

Andersen, Torben M. (2007) “The Scandinavian Model - Prospects and Challenges.” International Tax and Public Finance, forthcoming.

Angrist, Joshua D. and Alan B. Krueger (2001) "Instrumental Variables and the Search for Identification: From Supply and Demand to Natural Experiments.” Journal of Economic Perspectives, 15(4), 69-85.

Baumol, William J. (1990), “Entrepreneurship: Productive, Unproductive, and Destructive.” Journal of Political Economy, 98(5), 893-921.

Baumol, William J. (2002), The Free-Market Innovation Machine, Princeton and Oxford: Princeton University Press.

Bianchi, Milo and Magnus Henrekson (2005). ”Is Neoclassical Economics still Entrepreneurless?” Kyklos, 58(3), 353-377.

Birch, David L. and James Medoff (1994), “Gazelles.” In Lewis C. Solmon and Alec R. Levenson, eds., Labor Markets, Employment Policy and Job Creation, Boulder and London: Westview Press.

Blanchflower, David G. (2000), "Self-employment in OECD Countries.” Labour Economics, 7(3), 471-505.

Blau, Francine D. and Lawrence M. Kahn (1999), ”Institutions in the Labor Market.” In Orley Ashenfelter and David Card, eds., Handbook of Labor Economics Vol. 3, Amsterdam: NorthHolland.

Brown, Charles and James Medoff (1989), “The Employer Size Wage Effect.” Journal of Political Economy, 97(5), 1027-1059.

Buchanan, James M. (1980), ”Rent Seeking and Profit Seeking.” In James M. Buchanan and Roger Tollison, eds., Toward a Theory of the Rent-Seeking Society, Texas A\&M University Press.

Caballero, Ricardo (2007), Specificity and the Macroeconomics of Restructuring. Cambridge: MA: MIT Press.

Carree, Martin A., André van Stel, A. Roy Thurik and Sander Wennekers (2002), "Economic Development and Business Ownership: An Analysis Using Data of 23 OECD Countries in the Period 1976-1996.” Small Business Economics, 19(3), 271-290. 
Casson, Mark C. (2003). The Entrepreneur. An Economic Theory. $2^{\text {nd }}$ revised edition. Cheltenham: Edward Elgar.

Cohen, Wesley M. (2005), “Patents and Appropriation: Concerns and Evidence.” Journal of Technology Transfer, 30(1-2), 57-71.

Cowling, Mark (2007), "Small Firm CEOs and Outside Directorships: Tenure, Demonstration and Synergy Effects." Paper presented at the conference on Entrepreneurship: Law, Culture and the Labor Market, Chicago, March.

Coyne, Christopher J. and Peter T. Leeson, (2004), “The Plight of Underdeveloped Countries.” Cato Journal, 24(3), 235-249.

Daokui Li, David, Junxin Feng and Hongping Jiang (2006), "Institutional Entrepreneurs.” American Economic Review, 96(2), 358-362.

Davis, Steven J. and John Haltiwanger (1996), "Employer Size and the Wage Structure in U.S. Manufacturing." Annales d'Économie et de Statistique, 41/42, 323-367.

Davis, Steven J. and John Haltiwanger (1999), ”Gross Job Flows.” In Orley Ashenfelter and David Card, eds., Handbook of Labor Economics Vol. 3, Amsterdam: North-Holland.

Domar, Evsey D. and Richard A. Musgrave (1944), "Proportional Income Taxation and RiskTaking.” Quarterly Journal of Economics, 58(3), 388-422.

Douhan, Robin and Magnus Henrekson (2007), “The Political Economy of Entrepreneurship.” Mimeo, Research Institute of Industrial Economics, Stockholm.

Drucker, Peter F. (1976), The Unseen Revolution: How Pension Fund Socialism Came to America, London: Heinemann.

Feldstein, Martin S. and Joel Slemrod (1980), "Personal Taxation, Portfolio Choice, and the Effect of the Corporation Income Tax.” Journal of Political Economy, 88(5), 854-866.

Fonseca, Raquel, Pierre-Carl Michaud and Theptida Sopraseuth (2007), "Entrepreneurship, Wealth, Liquidity Constraints and Start-up Costs.” Paper presented at the conference on Entrepreneurship: Law, Culture and the Labor Market, Chicago, March.

Gerschenkron, Alexander (1962), Economic Backwardness in Historical Perspective, Cambridge, MA: Harvard University Press.

Gompers, Paul A. and Josh Lerner (2001), The Money of Invention: How Venture Capital Creates New Wealth, Cambridge, MA: Harvard University Press.

Hébert, Robert F. and Albert N. Link (2006), "Historical Perspective on the Entrepreneur." Foundations and Trends in Entrepreneurship, 2(4), 261-408.

Hessels, Jolanda, André van Stel, Peter Brouwer and Sander Wennekers (2006), "Social Security Arrangements and Early-stage Entrepreneurial Activity: An Empirical Analysis.” SCALESpaper N200518, EIM, Zoetermeer.

Jaffee, Adam B. and Josh Lerner (2004), Innovation and Its Discontents: How Our Broken Patent System Is Endangering Innovation and Progress, and What to Do about It? Princeton, NJ: Princeton University Press.

Johansson, Dan (2004). ”Economics without Entrepreneurship or Institutions: A Vocabulary Analysis of Graduate Textbooks." Econ Journal Watch, 1(3), 515-538.

Jorgenson, Dale W. and Robert Landau, eds. (1993), Tax Reform and the Cost of Capital. An International Comparison, Washington D.C.: Brookings. 
Kanniainen, Vesa and Panu Poutvaara (2007), "Imperfect Transmission of Tacit Knowledge and Other Barriers to Entrepreneurship.” Paper presented at the conference on Entrepreneurship: Law, Culture and the Labor Market, Chicago, March.

King, Mervyn A. and Don Fullerton (1984), The Taxation of Income from Capital: A Comparative Study of the United States, the United Kingdom, Sweden and West Germany, Chicago: University of Chicago Press.

Kirzner, Israel M. (1973), Competition and Entrepreneurship, Chicago: University of Chicago Press.

Kirzner, Israel M. (1997), "Entrepreneurial Discovery and the Competitive Market Process: An Austrian Approach.” Journal of Economic Literature, 35(1), 60-85.

Knight, Frank H. (1921), Risk, Uncertainty and Profit, New York: Houghton Mifflin.

Lallemand, Thierry and François Rycx (2006), "Establishment Size and the Dispersion of Wages: Evidence from European Countries.” Applied Economics Quarterly, 52(4), 309-336.

Lazear Edward P. (2005), “Entrepreneurship.” Journal of Labor Economics, 23(4), 649-680

Lazerson, Mark H. and Gianni Lorenzoni (1999), ”The Firms That Feed Industrial Districts: A Return to the Italian Source.” Industrial and Corporate Change, 8(2), 235-266.

Lewin, Peter and Steven E. Phelan (2002), "Rents and Resources: A Market Process Perspective.” In Nicolai J. Foss and Peter G. Klein, eds., Entrepreneurship and the Firm, Cheltenham: Edward Elgar.

Lindbeck, Assar (2006), “Economic-Social Interaction during China’s Transition.” IFN Working Paper No. 680, Research Institute of Industrial Economics, Stockholm.

Lindbeck, Assar, Mårten Palme and Mats Persson (2006), "Job Security and Work Absence: Evidence from a Natural Experiment.” IFN Working Paper No. 660, Research Institute of Industrial Economics, Stockholm.

Loveman, Gary and Walter Sengenberger (1991), ”The Reemergence of Small-Scale Production: An International Comparison.” Small Business Economics, 31(1), 1-37.

Misher, Norman (1984), "Tax Consequences of Exercising An Incentive Stock Option with Stock of the Granting Corporation.” The Tax Executive, July, 357-363.

Murphy, Kevin M, Andrei Shleifer and Robert W. Vishny (1991), ”The Allocation of Talent: Implications for Growth.” Quarterly Journal of Economics, 106(2), 503-530.

Nordhaus, William D. (2004), "Schumpeterian Profits in the American Economy: Theory and Measurement.” NBER Working Paper 104333.

North, Douglass C. (1981), Structure and Change in Economic History, New York: W. W. Norton.

North, Douglass C. (1990), Institutions, Institutional Change and Economic Performance, Cambridge: Cambridge University Press.

OECD (1994), ”Labor Standards and Economic Integration.” OECD Employment Outlook, July, $137-166$.

Oi, Walter and Todd L. Idson (1999), "Firm Size and Wages.” In Orley Ashenfelter and David Card, eds., Handbook of Labor Economics Vol. 3, Amsterdam: North-Holland.

Parker, Simon C. (2004), The Economics of Self-employment and Entrepreneurship, Cambridge, Cambridge University Press. 
Parker, Simon C. (2007), “Law and the Economics of Entrepreneurship.” Paper presented at the conference on Entrepreneurship: Law, Culture and the Labor Market, Chicago, March.

Reynolds, Paul D., William D. Bygrave, Erkko Autio and Michael Hay (2002), Global Entrepreneurship Monitor Executive Report 2002, Babson College and London Business School.

Robson, Martin T. (2003), "Does Stricter Employment Protection Legislation Promote Selfemployment?” Small Business Economics, 21(3), 309-319.

Rodrik, Dani, Arvind Subramanian and Francesco Trebbi (2004), "Institutions Rule: The Primacy of Institutions over Geography and Integration in Economic Development.” Journal of Economic Growth, 9(2), 131-165.

Rosenberg, Nathan and Luther E. Birdzell (1986), How the West Grew Rich: The Economic Transformation of the Industrial World. New York: Basic Books.

Schuetze, Herbert J. and Donald Bruce (2004), “Tax Policy and Entrepreneurship.” Swedish Economic Policy Review, 11(2), 233-265.

Schumpeter, Joseph A. (1934), The Theory of Economic Development, Cambridge, MA: Harvard University Press.

Shane, Scott (2002), The Foundations of Entrepreneurship. Vol. I and II, Cheltenham: Edward Elgar.

Shapiro, Carl (2001), "Navigating the Patent Thicket: Cross Licenses, Patent Pools, and Standard Setting.” In Adam B. Jaffee, Josh Lerner and Scott Stern, eds., Innovation Policy and the Economy, Volume I. Cambridge, MA: MIT Press.

Siegel, Donald S, David Waldman and Albert N. Link (2003), “Assessing the Impact of Organizational Practices on the Relative Productivity of University Technology Transfer Offices: An Exploratory Study.” Research Policy, 32(1), 27-48

Storey, David J. (1994), Understanding the Small Business Sector. London: Routledge.

Torrini, Riccardo (2005), "Cross-country Differences in Self-employment Rates: The Role of Institutions.” Labour Economics, 12(4), 661-683.

van Stel, André, Martin A. Carree and A. Roy Thurik (2005), "The Effect of Entrepreneurial Activity on National Economic Growth.” Small Business Economics, 24(3), 311-321.

van Stel, André, David Storey and A. Roy Thurik (2007), "The Effect of Business Regulations on Nascent and Young Business Entrepreneurship.” Small Business Economics, 28(2-3), 171186.

Wennekers, Sander and A. Roy Thurik, (1999), "Linking Entrepreneurship and Economic Growth.” Small Business Economics, 13(1), 27-56.

Wu, Shih-Yen (1989), Production and Entrepreneurship, Oxford: Basil Blackwell.

Young, Alwyn (1992), "A Tale of Two Cities: Factor Accumulation and Technical Change in Hong Kong and Singapore.” In Olivier J. Blanchard and Stanley Fischer, eds., NBER Macroeconomics Annual, Cambridge, MA: MIT Press.

Yu, Tony Fu-Lai (2001), “An Entrepreneurial Perspective of Institutional Change.” Constitutional Political Economy, 12(3), 217-236.

Zider, Bob (1998), "How Venture Capital Works.” Harvard Business Review, NovemberDecember, 131-139. 